Article

\title{
Bioremediation of Polluted Soil Sites with Crude Oil Hydrocarbons Using Carrot Peel Waste
}

\author{
Latifa Hamoudi-Belarbi ${ }^{1,2}, *$, Safia Hamoudi ${ }^{3}$, Khaled Belkacemi ${ }^{3, \dagger}{ }^{\dagger}$, L'Hadi Nouri ${ }^{2}$, \\ Leila Bendifallah ${ }^{4}$ and Mohamed Khodja ${ }^{5}$ \\ 1 Department of Nature and Life Sciences, Faculty of Sciences, University of Algiers, 1 Benyoucef Benkhedda, \\ 2 Street Didouche Mourad, Algiers 16000, Algeria \\ 2 Laboratory of Food Technology, Faculty of Engineer Sciences, University of M'Hamed Bougara, \\ Boumerdès 35000, Algeria; lhadinouri@gmail.com \\ 3 Department of Soil Sciences and Agri-Food Engineering, Centre in Green Chemistry and Catalysis (CGCC), \\ Université Laval, Quebec, QC G1V 0A6, Canada; safia.hamoudi@fsaa.ulaval.ca (S.H.); \\ Khaled.Belkacemi@fsaa.ulaval.ca (K.B.) \\ 4 Laboratory of Soft Technology, Valorization, Physical-Chemistry of Biological Materials and Biodiversity, \\ Department of Agronomy, Faculty of Sciences, University of M’Hamed Bougara, Boumerdès 35000, Algeria; \\ leila.bendifallah@gmail.com \\ 5 Laboratries Division/ SONATRACH, Avenue 1st November, Boumerdès 35000, Algeria; \\ mohamed.khodja@ep.sonatrach.dz \\ * Correspondence: Latifa.Hamoudi.1@ulaval.ca; Tel./Fax: +213-24-911-116 \\ + The late professor Khaled Belkacemi passed away in the terrorist attack perpetrated at Quebec City on \\ 29 January 2017.
}

Received: 6 September 2018; Accepted: 15 November 2018; Published: 17 November 2018

\begin{abstract}
The biostimulation potentials of carrot peel waste and carob kibbles for bioremediation of crude petroleum-oil polluted soil were investigated. Temperature, $\mathrm{pH}$, moisture, total petroleum hydrocarbon (TPH), and changes in microbial counts during 45 days were monitored when $4 \mathrm{~mL}$ of carrot peel waste or carob kibbles media were added to $200 \mathrm{~g}$ of crude oil polluted soil samples. Gas chromatography-flame ionization detection (GC-FID) was used to compare hydrocarbon present in the crude oil polluted soil and in pure fuel, composition of crude oil polluted soil was analyzed by X-ray diffraction (XRD), and the TPH was measured by distillation using distiller mud. The results showed that, at the end of experiments, the concentration of TPH decreased in crude oil polluted soil containing carrot peel waste with a percentage of $27 \pm 1.90 \%$ followed by crude oil polluted soil containing carob kibbles $(34 \pm 1.80 \%)$ and in the unamended control soil $(36 \pm 1.27 \%)$, respectively. The $\log$ [Colony Forming Unit (CFU)/g] of total heterotrophic bacteria in the crude oil polluted soil increased from $10.46 \pm 0.91$ to $13.26 \pm 0.84$ for carrot peel waste, from $11.01 \pm 0.56$ to $11.99 \pm 0.77$ for carob kibbles and from $8.18 \pm 0.39$ to $8.84 \pm 0.84$ for control, respectively. Such results demonstrated that carrot peel could be used to enhance activities of the microbial hydrocarbon-degrading bacteria during bioremediation of crude petroleum-oil polluted soil.
\end{abstract}

Keywords: biodegradation; biostimulation; carrot peel waste; carob kibbles; crude oil polluted soil

\section{Introduction}

Crude oil is the most important source of energy worldwide; however, routine operations of extraction and drilling of this fossil energy resource cause serious environmental problems [1]. Crude oil contains a wide range of compounds that pose a significant risk for the environment and human health and have cytotoxic, mutagenic, and carcinogenic effects [2]. Reducing the petroleum hydrocarbon compounds in a polluted environment becomes a significant challenge for oil 
companies that are forced to conduct an adequate and effective treatment of these pollutant emissions. Thermal treatment, soil washing, soil vapor extraction, solidification, and stabilization are physical and chemical techniques used to treat petroleum hydrocarbon-polluted soil [3]. However, they are often expensive, ineffective, and rarely neutral [4].

Bioremediation of hydrocarbons in polluted soils is a promising treatment method [5,6]. Based on the principle of complete mineralization or transformation of petroleum products into less toxic forms by different groups of microorganisms [7], bioremediation is the most effective, non-invasive, the least expensive and eco-friendly technique [8-10]. Conservation of soil texture and characteristics are among the advantages of bioremediation. Besides, physical and chemical properties of the soil, such as aeration, $\mathrm{pH}$, water-holding capacity, and ion exchange capacity can be improved after bioremediation [11].

This process occurring naturally can be accelerated by bio-stimulation. This strategy is based on stimulation of the catabolic activity of indigenous microorganisms by the addition of nutrient-rich organic and inorganic materials, supplying oxygen or other electron acceptors, and by maintaining suitable conditions of temperature, $\mathrm{pH}$, and moisture [7,12,13]. In arid areas, where soils are poor in organic and mineral nutrient matters, and are usually subjected to extreme environmental conditions (high temperatures and irradiance) [14]; the rate of degradation of complex hydrocarbon compounds from crude oil polluted sites is usually limited by biodegrading microbiota [15].

Bio-stimulants with promising results, like carob kibbles, sugarcane bagasse, sugarcane molasses, wheat straw, banana skin, yam peel, saw dust, spent brewing grain, rice husk, and coconut shell have been used earlier [16-19].

Two important hypotheses have been proposed to elucidate the mechanisms involved in the enhanced removal of hydrocarbon petroleum products from soils using bio-stimulants [20]. The first one suggested that, nutrient matters, especially nitrogen and phosphorus, usually considered as the limiting factors for the bioremediation of contaminated soils [21], once provided by the bio-stimulants, enhance substantially the growth of hydrocarbon degrading bacteria [22-26].

The second hypothesis is based on the ability of bio-stimulants to release biosurfactants that increase the bioavailability of poorly soluble hydrocarbon petroleum compounds [27-29]. For instance, Yi and Crowley [27] found that plants produced fatty acids acted as biosurfactants significantly enhancing pyrene and benzo[a]pyrene degradation when added directly to polluted soil.

Furthermore, bioavailability is governed by the interactions between microorganisms and the environmental conditions ( $\mathrm{pH}$, temperature, etc.) as well as the physico-chemical interactions between polluting compounds and the soil matrix [30]. Therefore, bioavailability of polluting hydrocarbons to degrading bacteria can be related to soil mineral composition, which is usually assessed using X-ray diffraction analysis [26,31].

The aim of this work was to study the efficacy of two bio-stimulants, i.e., carrot peel waste and carob kibbles, to degrade crude oil polluted soil as a judicious alternative to expensive physical and chemical treatments.

\section{Materials and Methods}

\subsection{Crude Oil Polluted Soil Origin}

Crude oil polluted soil was collected at a disused oil-drilling quagmire in the Hassi Messaoud field (Algeria). Samples were collected at 0-50 cm depth using a stainless steel sampler, placed in appropriate containers thoroughly mixed therein.

\subsection{Carrot Peel Waste Medium}

Carrots, Daucus carota, were purchased from a local vegetable market then peeled. The peels were mixed and macerated at a ratio of $1 \mathrm{~kg}$ in $2.5 \mathrm{~L}$ of distilled water at $85^{\circ} \mathrm{C}$ for 45 min with continuous 
stirring [32]. After filtration and decantation, the medium was autoclaved at $120^{\circ} \mathrm{C}$ for $20 \mathrm{~min}$ and stored at $4{ }^{\circ} \mathrm{C}$ before its use as a bio-stimulating medium.

\subsection{Carob Kibbles Medium}

Dry pods of carob, Ceratonia siliqua, were obtained from locality of Ighil-Ali (Bejaïa, Algeria). Pods were cut and manually de-seeded. Carob kibbles were then pitted and macerated at a ratio of $1 \mathrm{~kg}$ in $2.5 \mathrm{~L}$ of distilled water at $85^{\circ} \mathrm{C}$ for $45 \mathrm{~min}$ with continuous stirring [32]. The mash was filtered, decanted, autoclaved at $120^{\circ} \mathrm{C}$ for $20 \mathrm{~min}$, and stored at $4{ }^{\circ} \mathrm{C}$ before its use as a bio-stimulating medium.

\subsection{Experimental Design}

In order to evaluate the effectiveness of hydrocarbon degradation, $4 \mathrm{~mL}$ of carrot peel waste or carob kibbles media were added to $200 \mathrm{~g}$ of crude oil polluted soil samples, resulting in slurry mixtures placed in circular cells and mixed thoroughly. Experiments were also conducted on unamended control soil samples for the sake of comparison. A total of 6 cells were used in the study and each treatment was carried out in duplicate. Cells containing treatment materials or the control were run in the open air and mixed every 3 days to ensure homogenous distribution during 45 days of remediation tests.

\subsection{Characterization of Carrot Peel Waste and Carob Kibbles}

Total soluble solids (TSS) were determined by desiccation in the oven at $105^{\circ} \mathrm{C}$ until a constant weight while $\mathrm{pH}$ was determined using $\mathrm{pH}$ meter (Accumet AE150 instrument; Fisher Scientific, Illkirch, France). Calcium, magnesium, phosphorus, nitrate and nitrite were determined by digital titrator. All measurements were performed in triplicate, and the mean was used for analyses.

\subsection{Physico-Chemical Characterization of Crude Oil}

\subsubsection{X-ray Diffraction (XRD)}

The soil samples were prepared for XRD measurement by orienting them in a glass slide following standard procedure. The slides were air dried and placed in a desiccators containing silica gel to prevent rehydration. X-ray powder diffraction of the prepared materials was carried out using a Philips diffractometer with nickel-filtered $\mathrm{Cu} K \alpha$ radiation of wavelength $1.5406 \AA$. Powder diffraction patterns were obtained between $10^{\circ}$ and $80^{\circ}$ with a scan speed of 5 degree $/ \mathrm{min}$. Data were interpreted by reference to $X^{\prime}$ Pert accompanying software program High Score Plus in conjunction with data from the ICDD (International Centre for Diffraction Data) Powder Diffraction File [33].

\subsubsection{Gas Chromatographic (GC-FID) Analysis}

The soil samples were extracted using methylene chloride solvent. Aliquot of extracts as well as pure fuel were analyzed using an Agilent 6890 Series II gas chromatograph equipped with a flame ionization detector and an on-column injector. Separation was achieved using a $25 \mathrm{~m} 0.32 \mathrm{~mm}$ internal diameter fused silica capillary column. The operating conditions were: Temperature program $40^{\circ}-280^{\circ} \mathrm{C}$ at $4{ }^{\circ} \mathrm{C} / \mathrm{min}$, injector temperature $280^{\circ} \mathrm{C}$, detector temperature $280{ }^{\circ} \mathrm{C}$, and carrier gas: $\mathrm{H}_{2}(1 \mathrm{~mL} / \mathrm{min})$.

\subsubsection{Physicochemical Parameters Measurements of Crude Oil Polluted Soil}

The temperature and $\mathrm{pH}$ were determined using thermometer (MRC 201, France) and, $\mathrm{pH}$ meter (Accumet AE150 instrument; Fisher Scientific, Illkirch, France), respectively.

Total petroleum hydrocarbon (TPH) percentage of soil samples was measured by distillation using Fann distiller according to API recommendations [34]. This method is used to determine the percentage of water/oil in the crude oil. $20 \mathrm{~mL}$ of each soil sample is placed in a distiller, then heated up to $800^{\circ} \mathrm{C}$. The vapors of water and oil are then condensed back into liquid form and collected (distillate). After about 30 to $60 \mathrm{~min}$ of decantation, the volumes of water and oil are read directly. 
After distillation, the remaining mass of mud is weighed. The percentages of water and oil are directly determined. Two replications were conducted for all measurements. The residual moisture of crude oil polluted soil samples was determined (in duplicate) by the difference in weight before and after drying in a vacuum oven at $105^{\circ} \mathrm{C}$ for $3 \mathrm{~h}$ in the presence of $\mathrm{P}_{2} \mathrm{O}_{5}$.

\subsection{Microbiological Analysis}

Two replicate samples from each crude oil polluted soil amended with carrot peel waste, carob kibbles, and unamended control soil were withdrawn at the end of second, fourth, and sixth week of the study for the enumeration of total aerobic heterotrophic bacteria. Aliquots of serially diluted samples $(0.1 \mathrm{~mL})$ were plated on nutrient agar medium (Oxoid). All inoculated plates were incubated aerobically at room temperature and counted after $48 \mathrm{~h}$.

\subsection{Statistical Analysis}

Data were statistically analyzed by Data Analysis Tool pack of Microsoft Office Excel 2007 (Microsoft, New York, NY, USA). Excel was used for data management and exploratory data analyses. Excel was also used for drawing of graphs and bar charts regarding temperatures, $\mathrm{pH}, \mathrm{TPH}$, residual moisture, and microbiological analysis of crude oil polluted soil amended with carrot peel waste, carob kibbles, and unamended control soil during 45 days of treatments. $p<0.05$ was used to judge statistical significance.

\section{Results and Discussion}

\subsection{Properties of Carrot Peel Waste and Carob Kibbles}

Table 1 shows the chemical composition, total soluble solids (TSS), moisture content, and $\mathrm{pH}$ of carrot peel waste and carob kibbles. Calcium, magnesium, and phosphorus, are the major elemental components of all carrot peel waste and carob kibbles; while nitrate and nitrite are in trace. Magnesium is at lower concentrations in all carrot peel waste and carob kibbles (7.29 \pm 0.30 and $6.28 \pm 0.20$ respectively). However, phosphorus is at higher concentration in carrot peel compared to carob kibbles ( $25 \pm 1.20$ and $7.1 \pm 0.20$ respectively). Cutright [35] found that phosphorus increased the degradation of a poly aliphatic hydrocarbon mixture by aerobic bacteria. Besides, this important nutrient together with nitrogen, stimulated microbial growth and led to synthesize enzymes required to degrade petroleum hydrocarbon [36]. Concentration of nitrogen in the root of carrot (1400 ppm) from data previously compiled by the US Department of Agriculture (USDA) (http: / www.ars-grin.gov / duke/) [37] demonstrated the importance of nitrogen for cellular protein and cell wall configuration of microorganisms, while phosphorus is essential for synthesis of nucleic acids, cell membrane, and ATP formation [38]. While in an arid area where soils have low contents of organic matter and low numbers of microorganisms, stimulation of degrading bacteria by phosphorus present in carrot peel waste contributed to initiate remediation of crude oil polluted soil.

Table 1. Mineral contents and physico-chemical properties of carrot peel waste and carob kibbles media.

\begin{tabular}{ccc}
\hline Elements $(\mathrm{mg} / \mathrm{L})$ & Carrot Peel Waste & Carob Kibbles \\
\hline Calcium & $32.06 \pm 2.01^{\mathrm{a}}$ & $26.08 \pm 2.30^{\mathrm{a}}$ \\
Magnesium & $7.29 \pm 0.30$ & $6.28 \pm 0.20$ \\
Phosphorus & $25.10 \pm 1.20$ & $7.1 \pm 0.20$ \\
Nitrate & $3.01 \pm 0.20$ & $1.02 \pm 0.10^{\mathrm{a}}$ \\
Nitrite & $0.5 \pm 0.02$ & $0.4 \pm 0.01$ \\
\hline Parameters & \\
\hline Total solid extract $(\%)$ & $19.24 \pm 2.04^{\mathrm{a}}$ & $30.45 \pm 2.40^{\mathrm{a}}$ \\
Moisture $(\%)$ & $80.76 \pm 4.30$ & $69.55 \pm 3.40$ \\
pH & $5.31 \pm 0.95$ & $5.32 \pm 0.90$ \\
\hline a Mean and standard error of three repetitions.
\end{tabular}


The total soluble solids (TSS) of carrot peel waste and carob kibbles were $19.24 \pm 2.04 \%$ and $30.45 \pm 2.40 \%$, respectively. These values are due to the degree of tissue breakdown, releasing more components that contribute to soluble solids [39]. $\mathrm{pH}$ values of carrot peel waste and carob kibbles explain the ability of microorganisms to growth in these media that tolerate very wide ranges from 2.4 to 8.6 .

\subsection{Mineral Composition of Crude Oil Polluted Soil}

The X-ray diffraction (XRD) results for minerals present in crude oil polluted soil are shown in the Table 2. Results indicate that the main constituents of crude oil polluted soil fractions are, for non-clay minerals, quartz, barite, albite, anhydrite, and calcite. Illite was the major clay component. According to the XRD mineralogical study conducted by Khodja [40], the unpolluted sandy soil withdrawn from sites nearby a petroleum oil field showed a predominance of quartz, microcline and gypsum. These results indicate that the other minerals present in crude oil polluted soil are attributed to the materials brought to the soil surface by the drilling fluids used during the drilling operations.

Table 2. X-ray diffraction analysis results for minerals present in crude oil polluted soil.

\begin{tabular}{|c|c|c|c|}
\hline Minerals & Crude Oil Polluted Soil & Unpolluted Soil [40] & Chemical Formula \\
\hline \multirow{10}{*}{$\begin{array}{l}\text { Non-clay } \\
\text { minerals }\end{array}$} & Barite & & $\mathrm{BaSO}_{4}$ \\
\hline & Quartz & Quartz & $\mathrm{SiO}_{2}$ \\
\hline & Calcite & - & $\mathrm{CaCO}_{3}$ \\
\hline & Dolomite & - & $\mathrm{CaMg}\left(\mathrm{CO}_{3}\right)_{2}$ \\
\hline & Anhydrite & - & $\mathrm{Ca}\left(\mathrm{SO}_{4}\right)$ \\
\hline & Albite & - & $\mathrm{NaAlSi}_{3} \mathrm{O}_{8}$ \\
\hline & Ankerite & - & $\mathrm{Ca}(\mathrm{Fe}, \mathrm{Mg}, \mathrm{Mn})\left(\mathrm{CO}_{3}\right)_{2}$ \\
\hline & Barium chloride hydrate & - & $\mathrm{BaCl}_{2} \cdot 2 \mathrm{H}_{2} \mathrm{O}$ \\
\hline & - & Microcline, ordered & $\mathrm{KAlSi}_{3} \mathrm{O}_{8}$ \\
\hline & - & Gypsum & $\mathrm{CaSO}_{4} \cdot 2 \mathrm{H}_{2} \mathrm{O}$ \\
\hline $\begin{array}{c}\text { Clay in low } \\
\text { concentrations }\end{array}$ & Illite, trioctahedral & - & $\mathrm{K}_{0.5}(\mathrm{Al}, \mathrm{Fe}, \mathrm{Mg})_{3} \cdot(\mathrm{Si}, \mathrm{Al})_{4} \mathrm{O}_{10}(\mathrm{OH})_{2}$ \\
\hline
\end{tabular}

(-) None.

The analysis of the organic fraction obtained after distillation of the crude oil polluted soil proved that oil contains fuel fractions (Figure $1 \mathrm{~A}, \mathrm{~B}$ ) with presence of hydrocarbons ranging from $\mathrm{C}_{10}$ to $\mathrm{C}_{20}$. These results are in large agreement with those found earlier by Marchal et al. [41]. Besides, hydrocarbons with carbon number varying from 12 to 25 were previously reported [42].

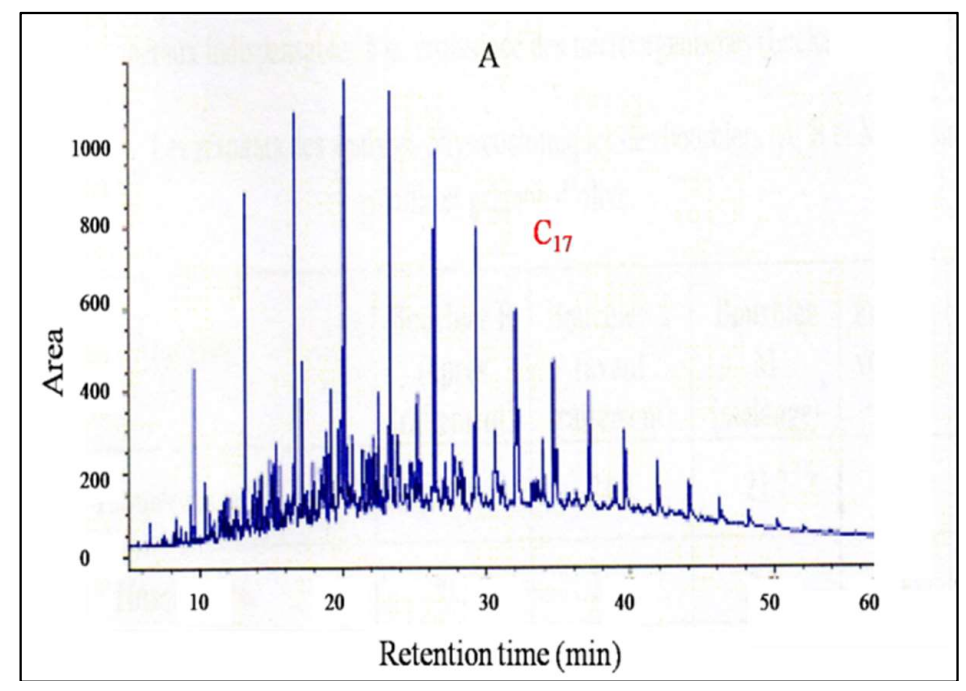

Figure 1. Cont. 


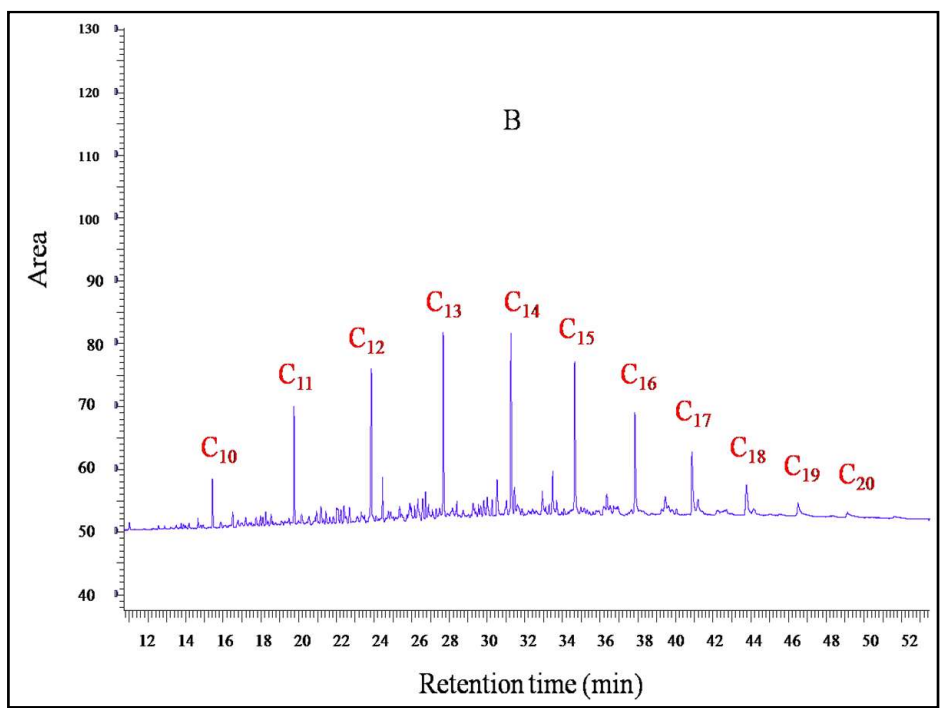

Figure 1. A conventional Gas Chromatography (GC) analysis of pure fuel (A) and crude oil polluted soil (B).

\subsection{Physicochemical Properties of Amended and Unamended Samples}

Physicochemical parameters of samples were analyzed for one week intervals during the study period. $\mathrm{pH}$ value of all amended soils with carrot peel waste, carob kibbles and unamended control soil was basic at the beginning of study $(8.5 \pm 0.26)$ (Figure $2 \mathrm{~A})$. However, the $\mathrm{pH}$ of the amended samples decreased gradually then increased to reach, at the end of study, $7.7 \pm 0.24$ for carrot peel waste amended soil and $7.61 \pm 0.30$ for carob kibbles amended soil, respectively. These results are in agreement with those found by Morgan and Atlas [43] who demonstrated that the optimum $\mathrm{pH}$ for hydrocarbon degradation in soil is between 6.5 and 8. Besides, Dibble and Bartha [44] concluded that $\mathrm{pH}$ 7.7-7.8 was optimal for hydrocarbons degradation and suggested that lower values of $\mathrm{pH}$ may result in partial inhibition of degradation.

Moisture content of crude oil polluted soil and amended with carrot peel waste ranged between $51.0 \pm 2.12 \%$ and $57.0 \pm 1.41 \%$ at the end of the treatment while that of crude oil polluted soil amended with carob ranged from $51.0 \pm 2.12 \%$ and $54.0 \pm 2.82 \%$ at the end of treatment, respectively (Figure $2 \mathrm{~B}$ ). However, the moisture content of control decreased from $51.0 \pm 2.12 \%$ to $36.0 \pm 4.24 \%$ at the end of treatment. Bacterial catabolism results in the production of energy and water. Besides, moisture is a limiting factor during biodegradation [45].

Figure $2 \mathrm{C}$ shows the evolution of temperature as a function of time throughout the study. According to Atlas [46], the effect of temperature on the physical nature and chemical composition of the oil, rate of hydrocarbon metabolism by microorganisms and composition of the microbial community, influences petroleum biodegradation. At the beginning of the study, the temperature of crude oil unamended and amended soil was approximately $21.8{ }^{\circ} \mathrm{C} \pm 0.28$. An increase in soil temperature was obtained for all samples after 15 days, followed by gradual decreasing then stabilization at $21.3{ }^{\circ} \mathrm{C} \pm 0.42$ for unamended soil control at the end of the study, while temperature values of amended samples continue their progression. These results may be due to the intensity of the metabolic activity of biodegrading microbiota present in carrot peel waste and carob kibbles amended crude oil soil. During microbial activities, big and complexes molecules are fragmented with the liberation of energy; some of this energy is captured and used for anabolism; the rest is released as heat [47]. Higher temperature increased the rate of hydrocarbon metabolism [48]. Moreover, earlier studies demonstrated that, in the laboratory, hydrocarbon degradation occurred within temperatures ranging from 4 to $30^{\circ} \mathrm{C}[49,50]$. 

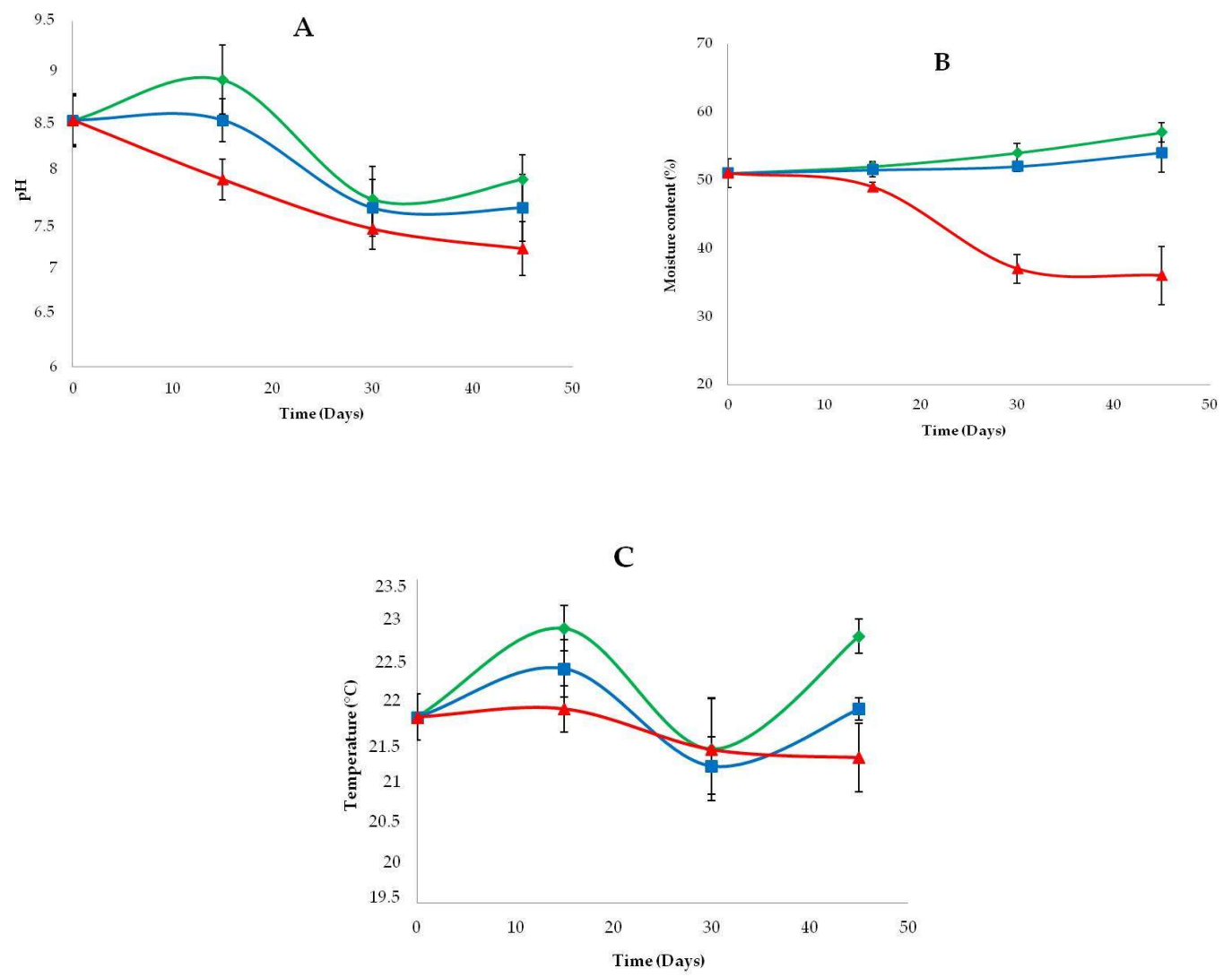

Figure 2. Evolution of $\mathrm{pH}(\mathbf{A})$, moisture (B), and temperature (C) during 45 days of treatment. Treatment with carrot peel waste $(\checkmark)$; Treatment with carob kibbles ( $\square$ ); and Control without treatment $(\Delta)$. Error bars represent the standard error of replicates.

\subsection{Crude Oil Polluted Soil Degradation}

In this study, distillation was used to determine total petroleum hydrocarbon (TPH) in the crude oil polluted samples (Figure 3). At the end of the experiment ( 45 days), the crude oil in the amended samples was attenuated. With initial concentration of TPH about $38 \pm 1.4 \%$, corresponding to $3.60 \mathrm{~g} / \mathrm{kg}$ at the beginning of the study for all samples, a difference in the concentration of TPH obtained at different time intervals in the carrot peel waste and carob amended samples with percentages of $31 \pm 0.67 \%$ and $37 \pm 1.37 \%$ after 15 days, $29.5 \pm 0.70 \%$ and $35 \pm 1.51 \%$, respectively at the end of the 30th day were shown. For the unamended control soil, reduction in the amount of TPH was gradual at the end of the 15th day, and the 30th day of study, with percentages of $37.6 \pm 1.20 \%$ and $36 \pm 0.52 \%$, respectively. By the end of the study, the decrease in the amount of TPH in carrot peel waste amended, carob kibbles amended and unamended samples were $27 \pm 1.90 \%, 34 \pm 1.80 \%$ and $36 \pm 1.27 \%$, respectively. The significant decrease in the content of TPH in the carrot peel waste amended sample compared to the carob kibbles amended sample, and unamended sample at different time intervals of study can be attributed to two factors [27,36,37,51]. First, the additional nutrient nitrogen and phosphorus contained in the carrot peel waste stimulated microbial growth and led to synthesized enzymes required to degrade petroleum hydrocarbon compounds [36]. On the other hand, carrots are known to release linoleic acid, which can increase the bioavailability of poorly soluble hydrocarbon petroleum compounds, as previously reported [27-29,51]. 


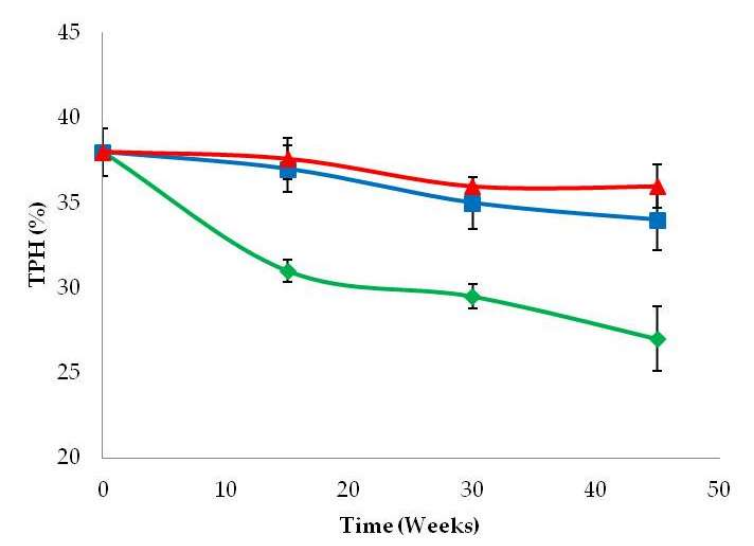

Figure 3. The rate of total petroleum hydrocarbon (TPH) during 45 days of treatment. Treatment with carrot peel waste $(\diamond)$; Treatment with carob $(\square)$; and Control without treatment $(\boldsymbol{\Delta})$. Error bars represent the standard error of replicates.

Several hypotheses have been proposed to explain the mode of action of linoleic acid [51]. During degradation, selective enrichment of hydrocarbons biodegrading bacteria would occur in the presence of linoleic acid. A second possibility is based on the ability of linoleic acid, by acting as a biosurfactant, to increase bioavailability of hydrocarbons to biodegrading bacteria [51]. The last possibility stipulated that linoleic acid increased the attachment of bacteria to the hydrophobic sites that adsorb hydrocarbons by coating the soil particles. High concentration of linoleic acid in roots of carrot compared to that of husk carob fruits (67\% and $28.68 \%$, respectively), found in compiled data by the USDA and available on the Internet (http: / / www.ars-grin.gov / duke) [37] confirmed the effectiveness of biodegradation by carrot.

\subsection{Microbial Counts}

The log [Colony Forming Unit (CFU)/g] of crude petroleum oil polluted soil in the presence of carrot peel waste as organic amendment ranged between $10.46 \pm 0.91$ at the end of the second week and $13.06 \pm 0.84$ at the end of the sixth week of treatment, while that of crude petroleum oil polluted soil amended with carob ranged from $11.01 \pm 0.56$ at the second week and $11.99 \pm 0.77$ at the end of the sixth week of treatment, respectively (Figure 4). However, the log CFU/g of control crude petroleum oil polluted unamended soil was lower than those amended with carrot peel waste and carob and ranged between $8.18 \pm 0.39$ at the end of the second week and $8.84 \pm 0.84$ at the end of the sixth week of treatment, respectively. Crude oil polluted soil amended with organic matter may stimulate growth of the indigenous oil degrading microbiota in it [18]. Similar observations have been reported using organic amendment [52]. By the end of the study, population of indigenous oil degrading microbiota increased rapidly, which corresponds to high availability of hydrocarbons during these periods [53]. The main reason for the occurrence of higher log CFU of bacteria when carrot peel waste is used as organic amendment for decontamination of crude oil polluted soil in comparison to carob kibbles amended crude oil polluted soil and unamended soil can be due, as explained earlier, to the presence of considerable quantities of $P$ in carrot peel waste $(25.10 \pm 1.20 \mathrm{mg} / \mathrm{L})$, which is a necessary nutrient for bacterial biodegradative activities [54]. In addition, production of linoleic acid biosurfactant by carrot increases the solubility and availability of hydrocarbons to biodegrading bacteria [54] and contributes to the biodegradation of petroleum hydrocarbons. Desert soils have been previously shown to be nutrients-limited [55]. 


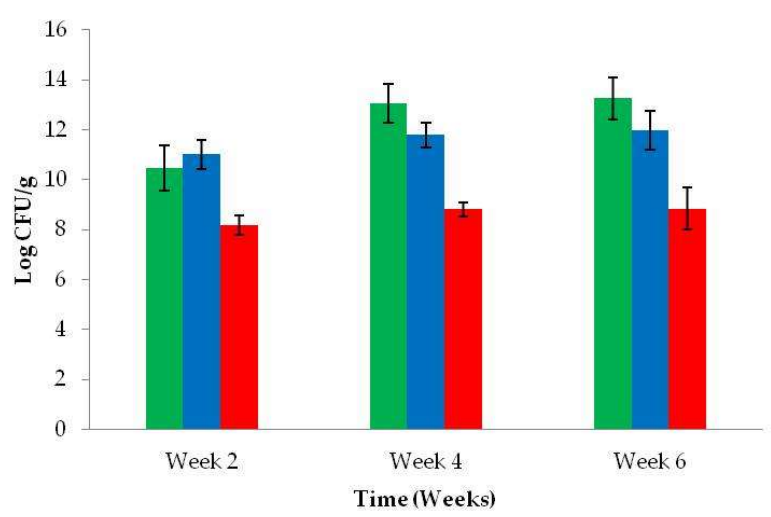

Figure 4. Evolution of microbial count during 6 weeks (45 days) of treatment. Treatment with carrot peel waste ( $\square$ ); Treatment with carob ( $\square)$; and Control without treatment $(\square)$. Error bars represent the standard error of replicates. CFU: Colony Forming Unit.

\section{Conclusions}

In conclusion, this study demonstrated that bio-stimulation of biodegrading crude oil microbiota with carrot peel waste enhanced degradation of crude oil under laboratory conditions. The TPH degradation in the crude oil contaminated soil was enhanced by bio-stimulation with nutrients present in the carrot peel waste in comparison to carob kibbles and control. Degradation of TPH increased after 45 days of incubation during bioremediation. The biodegrading crude oil microbiota in the crude oil polluted soil was positively related to TPH degradation efficiency during bio-remediation. Carrot peel waste, containing high amounts of phosphorus, enhanced bioremediation of crude oil polluted soil by increasing microbial activities of biodegrading indigenous microbiota. Also, linoleic acid produced by carrot peel waste, increased the solubility and availability of hydrocarbons to biodegrading bacteria.

Author Contributions: Conceptualization, L.H.-B., S.H., K.B., L.N. and L.B.; Methodology, L.H.-B. and M.K.; Writing—original draft, L.H.-B.; Writing—review \& editing, S.H.

Funding: This research received funding from the Algerian Ministry of High Education and Scientific Research.

Acknowledgments: The authors gratefully acknowledge the Algerian Ministry of High Education and Scientific Research for financial support.

Conflicts of Interest: The authors declare no conflict of interest.

\section{References}

1. Romanus, A.A.; Ikechukwu, E.F.; Patrick, A.S.; Goddey, U.; Helen, O. Efficiency of plantain peel and Guinea corn shaft for bioremediation of crude oil polluted soil. J. Microbiol. Res. 2015, 5, 31-40.

2. Ramirez, M.I.; Arevalo, A.P.; Sotomayor, S.; Bailon-Moscoso, N. Contamination by oil crude extraction-Refinement and their effects on human health. Environ. Pollut. 2017, 231, 415-425. [CrossRef] [PubMed]

3. Dadrasnia, A.; Salmah, I.; Emenike, C.U.; Shahsavari, N. Remediation of oil contaminated media using organic material supplementation. Petrol. Sci. Technol. 2015, 33, 1030-1037. [CrossRef]

4. Minai-Tehrani, D.; Minoui, S.; Herfatmanesh, A. Effect of salinity on biodegradation of polycyclic aromatic hydrocarbons (PAHs) of heavy crude oil in soil. Bull. Environ. Contam. Toxicol. 2009, 82, 82-179. [CrossRef] [PubMed]

5. Soleimani, M.; Afyuni, M.; Hajabbasi, M.A.; Nourbakhsh, F.; Sabzalian, M.R.; Christensen, J.H. Phytoremediation of an aged petroleum contaminated soil using endophyte infected and non-infected grasses. Chemosphere 2010, 81, 1084-1090. [CrossRef] [PubMed]

6. Graj, W.; Lisiecki, P.; Szulc, A.; Chrzanowski, Ł.; Wojtera-Kwiczor, J. Bioaugmentation with petroleum-degrading consortia has a selective growth-promoting impact on crop plants germinated in diesel oil-contaminated soil. Water Air Soil Pollut. 2013, 224, 1-15. [CrossRef] [PubMed]

7. Esmaeil, A.S.; Akbar, A. Occurrence of Pseudomonas aeruginosa in Kuwait soil. Chemosphere 2015, 120, $100-107$. 
8. Abdulsalam, S.; Omale, A.B. Comparison of biostimulation and bioaugmentation techniques for the remediation of used motor oil contaminated soil. Braz. Arch. Biol. Technol. 2009, 52, 747-754. [CrossRef]

9. Perelo, L.W. In situ and bioremediation of organic pollutants in aquatic sediments. J. Hazard Mater. 2010, 177, 81-89. [CrossRef] [PubMed]

10. Silva-Castro, G.A.; Uad, I.; Rodríguez-Calvo, A.; González-López, J.; Calvo, C. Response of autochthonous microbiota of diesel polluted soils to land-farming treatments. Environ. Res. 2015, 137, 49-58. [CrossRef] [PubMed]

11. Nwogu, T.P.; Azubuike, C.C.; Ogugbue, C.J. Enhanced bioremediation of soil artificially contaminated with petroleum hydrocarbons after amendment with Capra aegagrus hircus (Goat) Manure. Biotechnol. Res. Int. 2015, 2015, 1-7. [CrossRef] [PubMed]

12. Baptista, S.J.; Cammarota, M.C.; Freire, D.D.D.C. Production of $\mathrm{CO}_{2}$ in crude oil bioremediation in clay soil. Braz. Arch. Biol. Technol. 2005, 48, 249-255. [CrossRef]

13. Andreolli, M.; Lampis, S.; Brignoli, P.; Vallini, G. Bioaugmentation and biostimulation as strategies for the bioremediation of a burned woodland soil contaminated by toxic hydrocarbons: A comparative study. J. Environ. Manag. 2015, 153, 121-131. [CrossRef] [PubMed]

14. Radwan, S. Phytoremediation for Oily Desert Soils. In Advances in Applied Bioremediation; Singh, A., Kuhad, R., Ward, O., Eds.; Springer: Berlin/Heidelberg, Germany, 2009; pp. 279-298.

15. Nyman, J.A. Effect of crude oil and chemical additives on metabolic activity of mixed microbial populations in fresh marsh soils. Microb. Ecol. 1999, 37, 152-162. [CrossRef] [PubMed]

16. Hamoudi-Belarbi, L.; Nouri, L.; Bendifallah, L.; Hamoudi, S.; Belkacemi, K. Biostimulation of microbial community by carob (Ceratonia siliqua) to degrade total petroleum hydrocarbon (TPH) in contaminated soil. In Recent Advances in Environmental Science from the Euro-Mediterranean and Surrounding Regions, EMCEI 2017; Advances in Science, Technology and Innovation IEREK Interdisciplinary Series for Sustainable Development; Kallel, A., Ksibi, M., Ben Dhia, H., Khélifi, N., Eds.; Springer: Cham, Switzerland, 2017; pp. 275-276.

17. Alotaibi, H.S.; Usman, A.R.; Abduljabbar, A.S.; Ok, Y.S.; Al-Faraj, A.I.; Sallam, A.S.; Al-Wabel, M.I. Carbon mineralization and biochemical effects of short-term wheat straw in crude oil contaminated sandy soil. Appl. Geochem. 2018, 88, 276-287. [CrossRef]

18. Abioye, P.O.; Aziz, A.A.; Agamuthu, P. Enhanced biodegradation of used engine oil in soil amended with organic wastes. Water Air Soil Pollut. 2010, 209, 173-179. [CrossRef]

19. Molina-Barahona, L.; Rodrıguez-Vázquez, R.; Hernández-Velasco, M.; Vega-Jarquın, C.; Zapata-Pérez, O.; Mendoza-Cantú, A.; Albores, A. Diesel removal from contaminated soils by biostimulation and supplementation with crop residues. Appl. Soil Ecol. 2004, 27, 165-175. [CrossRef]

20. Miya, R.K.; Firestone, M.K. Enhanced phenanthrene biodegradation in soil by slender oat root exudates and root debris. J. Environ. Qual. 2001, 30, 1911-1918. [CrossRef] [PubMed]

21. Zhou, E.; Crawford, R.L. Effects of oxygen, nitrogen and temperature on gasoline biodegradation in soil. Biodegradation 1995, 6, 127-140. [CrossRef] [PubMed]

22. Shahi, A.; Aydin, S.; Ince, B.; Ince, O. Reconstruction of bacterial community structure and variation for enhanced petroleum hydrocarbons degradation through biostimulation of oil contaminated soil. Chem. Eng. J. 2016, 306, 60-66. [CrossRef]

23. Beolchini, F.; Rocchetti, L.; Regoli, F.; Dell'Anno, A. Bioremediation of marine sediments contaminated by hydrocarbons: Experimental analysis and kinetic modeling. J. Hazard. Mater. 2010, 182, 403-407. [CrossRef] [PubMed]

24. Binet, P.; Portal, J.M.; Leyval, C. Fate of polycyclic aromatic hydrocarbons (PAH) in the rhizosphere and mycorrhizosphere of ryegrass. Plant Soil 2000, 227, 207-213. [CrossRef]

25. Atlas, R.M.; Raymond, R.L. Stimulated petroleum biodegradation. Crit. Rev. Microbiol. 1977, 5, 371-386. [CrossRef]

26. Dong, H.; Kukkadapu, R.K.; Fredrickson, J.K.; Zachara, J.M.; Kennedy, D.W.; Kostandarithes, H.M. Microbial reduction of structural Fe (III) in illite and goethite. Environ. Sci. Technol. 2003, 37, 1268-1276. [CrossRef]

27. Yi, H.; Crowley, D.E. Biostimulation of PAH degradation with plants containing high concentrations of linoleic acid. Environ. Sci. Technol. 2007, 41, 4382-4388. [CrossRef] [PubMed]

28. Yoshitomi, K.J.; Shann, J.R. Corn (Zea mays L.) root exudates and their impact on C-14-pyrene mineralization. Soil Biol. Biochem. 2001, 33, 1769-1776. [CrossRef] 
29. Reilley, K.A.; Banks, M.K.; Schwab, A.P. Dissipation of polycyclic aromatic hydrocarbons in the rhizosphere. J. Environ. Qual. 1996, 25, 212-219. [CrossRef]

30. Prokop, Z.; Nečasová, A.; Klánová, J.; Čupr, P. Bioavailability and mobility of organic contaminants in soil: New three-step ecotoxicological evaluation. Environ. Sci. Pollut. Res. 2016, 23, 4312-4319. [CrossRef] [PubMed]

31. Babin, D.; Vogel, C.; Zühlke, S.; Schloter, M.; Pronk, G.J.; Heister, K.; Spiteller, M.; Kögel-Knabner, I.; Smalla, K. Soil mineral composition matters: Response of microbial communities to phenanthrene and plant litter addition in long-term matured artificial soils. PLoS ONE 2014, 9, e106865. [CrossRef] [PubMed]

32. Acourene, S.; Tama, M. Utilisation des Dattes de Faible Valeur Marchande (Rebuts de Deglet-Nour, Tinissine et Tantboucht) Comme Substrat pour la Fabrication de la Levure Boulangère. Rev. Energ. Ren. 2001. Available online: https: / www.cder.dz/download/bio_1.pdf (accessed on 10 October 2018).

33. ICDD International Centre for Diffraction Data, Powder Diffraction File 2 database, Pennsylvania, USA. 1999. Available online: http:/ / www.icdd.com (accessed on 10 October 2018).

34. API. API RP-45: Recommended Practice for Analysis of Oil-Field Waters, 3rd ed.; API Publishing Services; American Petroleum Institute: Washington, DC, USA, 1998.

35. Cutright, T.J. Polycyclic aromatic hydrocarbon biodegradation and kinetics using Cunninghamella echinulata var. elegans. Int. Biodeterior. Biodegrad. 1995, 35, 397-408. [CrossRef]

36. Vidali, M. Bioremediation: An overview. Pure Appl. Chem. 2001, 73, 1163-1172. [CrossRef]

37. Duke, J. Phytochemical and Ethnobotanical Databases; USDA Agricultural Research Service: Washington, DC, USA, 1998. Available online: http:/ / www.ars-grin.gov/duke/ (accessed on 25 October 2017).

38. Swindell, C.M.; Aelion, C.M.; Pfaender, F.K. Influence of minerals and organic nutrients anaerobic biodegradation and the adaptation response of surface microbial communities. Appl. Environ. Microbiol. 1988, 54, 212-217.

39. Eissa, H.A.; Salama, M.F. Effect of macerate enzymes on the yield, quality, volatile compounds and rheological property of prickly pear juice. Nahrung/Food 2002, 46, 245-250. [CrossRef]

40. Khodja, M. Drilling Fluid: Performance Study and Environmental Considerations. Ph.D. Thesis, Institut National Polytechnique, Toulouse, France, February 2008.

41. Marchal, R.; Penet, S.; Solano-Serena, F.; Vandecasteele, J.P. Gasoline and diesel oil biodegradation. Oil Gas Sci. Technol. 2003, 58, 441-448. [CrossRef]

42. Vogel, T.; Ballerini, D. Biorestauration des sols et des aquifères contaminés par des hydrocarbures et des composés halogénés. Bull. Soc. Fr. Microbiol. 2001, 16, 204-209.

43. Morgan, P.; Atlas, R.M. Hydrocarbon biodegradation in soils and methods for soil biotreatment. Crit. Rev. Biotechnol. 1989, 8, 305-333. [CrossRef] [PubMed]

44. Dibble, J.T.; Bartha, R. The effect of environmental parameters on the biodegradation of oil sludge. Appl. Environ. Microbiol. 1979, 37, 729-739. [PubMed]

45. Kumari, B.; Singh, S.N.; Singh, D.P. Induced degradation of crude oil mediated by microbial augmentation and bulking agents. Int. J. Environ. Sci. Technol. 2016, 13, 1029-1042. [CrossRef]

46. Atlas, R.M. Microbial degradation of petroleum hydrocarbons: An environmental perspective. Microbiol. Rev. 1981, 45, 180-209. [PubMed]

47. Prescott, L.M.; Harley, J.P.; Klein, D.A. Microbiology, 6th ed.; McGraw-Hill Science: New York, NY, USA, 2004; pp. 154-196. ISBN -13.

48. Bossert, I.; Kachel, W.M.; Bartha, R. Fate of hydrocarbons during oily sludge disposal in soil. Appl. Environ. Microbiol. 1984, 47, 763-767. [PubMed]

49. Aislabie, J.; Saul, D.J.; Foght, J.M. Bioremediation of hydrocarbon-contaminated polar soils. Extremophiles 2006, 10, 171-179. [CrossRef] [PubMed]

50. Muangchinda, C.; Chavanich, S.; Viyakarn, V.; Watanabe, K.; Imura, S.; Vangnai, A.S.; Pinyakong, O. Abundance and diversity of functional genes involved in the degradation of aromatic hydrocarbons in Antarctic soils and sediments around Syowa Station. Environ. Sci. Pollut. Res. 2015, 22, 4725-4735. [CrossRef] [PubMed]

51. Kosaric, N. Biosurfactants and their application for soil bioremediation. Food Technol. Biotechnol. 2001, 39, 295-304.

52. Al-Kindi, S.; Abed, R.M. Comparing oil degradation efficiency and bacterial communities in contaminated soils subjected to biostimulation using different organic wastes. Water Air Soil Pollut. 2016, 227, 36. [CrossRef] 
53. Song, H.G.; Bartha, R. Effects of jet fuel spills on the microbial community of soil. Appl. Environ. Microbiol. 1990, 56, 646-651. [PubMed]

54. Marinescu, M.; Lacatusu, A.; Gament, E.; Plopeanu, G.; Carabulea, V.; Mihai, M. A review of biological methods to remediate crude oil polluted soil. Ann. Univ. Craiova-Agric. Montanol. Cadastre Ser. 2017, 46, 335-340.

55. Al-Saleh, E.; Hassan, A. Enhanced crude oil biodegradation in soil via biostimulation. Int. J. Phytoremediat. 2016, 18, 822-831. [CrossRef] [PubMed] 